\title{
EVALUASI ATAS KEBIJAKAN PENINGKATAN RASIO SISWA SMK : SMA DITELAAH DARI KESIAPAN SARANA DAN PRASARANA
}

\author{
M. Syaom Barliana ${ }^{1} \quad$ Johar Maknun $^{2} \quad$ Kunthi Herma D $^{3}$
}

\begin{abstract}
Abstrak :Kebijakan peningkatan rasio jumlah siswa SMK berbanding SMA menjadi 70 \% 30 pada tahun 2014, perlu diikuti oleh kebijakan peningkatan kualitas dan kuantitas guru, sarana dan prasarana, spektrum keahlian, dan daya serap lulusan di pasar kerja. Melalui penelitian deskriptif kuantitatif, penelitian ini mengungkap ketersediaan sarana dan prasarana seluruh SMK Negeri di kota Bandung saat ini, dan proyeksinya ke depan. Hasil penelitian menunjukkan bahwa pada kondisi sekarang, ketika perbandingan jumlah siswa SMK : SMA adalah 50 : 50, ternyata secara umum SMK Negeri baru memenuhi 75\% kelengkapan dan kualitas sesuai standar nasional sarana dan prasarana.
\end{abstract}

Abstract : The policy to increase ratio of the number of students between vocational high school (SMK) and senior high school (SMA) being 70:30 in 2014, needs to be supported by policy to improve both quality and quantity of teachers, infrastructures, diversification of skills, and absorption of graduates in job market. Using quantitative descriptive approach, this research reveals that availability of infrastructures in all vocational high schools in Bandung city at present, and how the projection in the future. The result of this research shows that at present situation, when the comparison of the number of students SMK:SMA is 50:50, it proves that generally SMK with state status just fulfill exactly about $75 \%$ equipment and quality in accordance with infrastructure national standards.

Kata kunci: Evaluasi kebijakan, rasio SMK, proyeksi, sarana dan prasarana, standar nasional

\section{PENDAHULUAN}

Dalam kerangka kebijakan makro, perekonomian Indonesia mengalami pemulihan setelah dilanda krisis pada pertengahan 1997 hingga 1998 meskipun kembali mengalami goncangan ketika terjadi krisis ekonomi global tahun 2008. Namun demikian secara umum beberapa indikator makroekonomi meliputi pertumbuhan ekonomi, inflasi, tingkat suku bunga, nilai kurs, dan indeks harga saham cenderung terus membaik atau stabil. Laporan terakhir bahkan menunjukkan penguatan peran investasi dan ekspor dalam pertumbuhan ekonomi. Pertumbuhan ekonomi seperti itu memiliki fundamental dan keberlanjutan yang lebih kuat dibandingkan pertumbuhan ekonomi yang didominasi oleh konsumsi. (Mustasya, 2005).

Persoalannya, perbaikan beberapa indikator makroekonomi tersebut ternyata belum diikuti oleh terbukanya kesempatan kerja yang lebih baik, terutama di sektor formal. Hal ini terlihat dari masih tingginya tingkat pengangguran dan besarnya jumlah pekerja di sektor informal yang relatif berpenghasilan rendah dibandingkan sektor formal. Padahal, pertumbuhan ekonomi tidak akan memberikan manfaat bagi kesejahteraan tanpa adanya kontribusi yang riil terhadap kesempatan kerja. Dari segi mikro, dilihat dari sudut pandang pendidikan dan ketenagakerjaan, jumlah pengangguran itu menunjukkan terjadinya kesenjangan yang lebar antara jumlah, jenis, dan kualifikasi keahlian yang tersedia dengan kebutuhan pasar kerja.

Menurut Kepala Badan Pusat Statistik (BPS), jumlah pengangguran di Indonesia hingga Agustus 2009 tercatat sebanyak 8,96 juta orang atau 7,87\%. Angka itu menurun dibanding Februari 2009 yang sebanyak 9,26 juta orang $(8,14 \%)$, maupun dibandingkan Agustus 2008 yang sebanyak 9,39 juta orang (8,39\%). Jumlah angkatan kerja di Indonesia pada Agustus 2009 mencapai 113,83 juta 
orang, bertambah 90 ribu orang dibanding jumlah angkatan kerja Februari 2009 sebesar 113,74 juta orang atau bertambah 1,88 juta orang dibanding Agustus 2008 sebesar 111,95 juta orang. Jumlah penduduk yang bekerja di Indonesia pada Agustus 2009 mencapai 104,87 juta orang, bertambah 380 ribu orang dibanding keadaan pada Februari 2009 sebesar 104,49 juta orang, atau bertambah 2,32 juta orang dibanding keadaan Agustus 2008 sebesar 102,55 juta orang.

Namun demikian, peningkatan lapangan kerja tersebut bukan dari sektor formal melainkan dari sektor informal. Kesempatan kerja informal yang mampu disediakan kedua sektor itu jauh lebih tinggi daripada kesempatan kerja formal. Ini berarti bahwa proses informalisasi kesempatan kerja sedang terjadi di dalam perekonomian Indonesia. Ini tidak sehat bagi perekonomian.

Untuk meningkatkan angkatan kerja dari sektor formal tentunya harus diikuti dengan SDM yang berkompeten di bidangnya. Masih kurangnya pendidikan yang dapat menyiapkan tenaga kerja sektor formal menyebabkan tingkat pengangguran juga masih tinggi. Data BPS menyebutkan, pada Agustus 2009, pekerja pada jenjang pendidikan SD ke bawah masih tetap tinggi yaitu sekitar 55,21 juta orang (52,65\%), sedangkan pekerja dengan pendidikan diploma hanya sebesar 2,79 juta orang $(2,66 \%)$ dan pekerja dengan pendidikan sarjana hanya sebesar 4,66 juta orang $(4,44 \%)$.

Salah satu penyebab tenaga kerja sektor formal masih rendah dibandingkan tenaga kerja sektor informal adalah masih adanya kesenjangan antara lulusan SMA dengan SMK. Peminat SMA lebih tinggi dari peminat SMK, padahal lulusan SMA hanya sedikit saja yang melanjutkan ke perguruan tinggi, selebihnya masuk ke dunia kerja. Kurangnya peminat SMK membuat pemerintah gencar mempromosikan SMK kepada masyarakat. Berbagai upaya pun dilakukan oleh pemerintah untuk menarik peminat SMK, seperti membuat iklan, meningkatkan infrastruktur, menambah jumlah tenaga pendidik, menyempurnakan bidang keahlian dan lain-lain.

Pada tahun 2005, muncul kebijakan tentang peningkatan rasio SMK : SMA sebesar 70:30 pada tahun 2014. Hal ini dikemukakan oleh Mendiknas, Bambang Sudibyo pada saat upacara peringatan Hari Pendidikan Nasional (Hardiknas) 2009 di Depdiknas, Jakarta, Sabtu (2/05/2009). Selain itu, Gubernur Jabar Ahmad Heryawan (Harian Umum Pakuan, 19/05/2009) juga mengatakan untuk mengejar target pemerintah provinsi memerlukan perencanaan dan blue print dalam penyediaan sarana dan prasarana SMK. Saat ini jumlah bangunan sekolah di Jabar menunjukkan SMK 52\% dan SMA 48\%, tapi jumlah siswanya masih banyak SMA. Data Dinas Pendidikan (Disdik) Jabar mencatat, SMK di Jabar ada 1.120 dan SMA 1.198 yang tersebar di 26 kabupaten/kota.

Sebelum pada tataran Jawa Barat atau Nasional, pada skala mikro kota Bandung, permasalahannya terletak pada dua hal. Pertama, pada kondisi sekarang, ketika perimbangan siswa SMK berbanding SMA adalah 50 : 50, apakah fasilitas pendidikan yang ada sudah memenuhi standar baik dari segi kualitas dan kuantitas? Kedua, bagaimana proyeksi fasilitas pendidikan kedepan, pada saat jumlah SMK dan SMA berbanding 70 : 30. Penelitian ini akan mencoba memfokuskan kepada hal pertama, sedangkan hal kedua dinalisis sebagai bagian dari rekomendasi dan penelitian lanjutan.

Atas dasar penelitian ini, diharapkan bermanfaat bagi para penentu kebijakan untuk menetapkan kebijakan yang didukung oleh analisis empirik dan bukan semata-mata oleh political common sense, tentang rasio perbadingan jumlah siswa SMK dan SMA yang proporsional dan tepat pada tahun 2014 dan seterusnya. Dengan dukungan analisis empirik dan proyeksi ini, rasio perbandingan jumlah siswa SMK dan SMA yang dianggap tepat, akan memperoleh landasan yang kuat di dalam penerapan kebijakannya secara konsisten. 


\section{B. Standar Sarana dan Prasarana SMK}

Dibandingkan dengan tahun 1980 atau 1990-an, jelas bahwa perkembangan SMK sekarang ini sudah jauh lebih maju, baik dari segi perubahan konsep dan paradigma, pengembangan kurikulum, pengembangan program, perkembangan kualitas pendidikan, diversifikasi keahlian yang ditawarkan, kualitas lulusan, maupun pasar kerja yang dituju. Namun demikian, dengan rencana "ambisius" peningkatan proporsi jumlah SMK, yang didorong oleh membaiknya citra SMK, maka tuntutan terhadap mutu juga akan jauh lebih tinggi.

Untuk memenuhi tuntutan mutu tersebut, paling tidak ada dua faktor krusial yang harus diantisipasi. Pertama, faktor jumlah dan mutu guru. Analisis berikut ini, yang diadopsi dari Mulyadi (2007), menunjukkan kerangka kebutuhan guru sesuai dengan rencana peningkatan jumlah siswa SMK. Jika memakai skema perbandingan siswa SMK dengan SMA (60 : 40) untuk proyeksi tahun 2007/2008 secara ideal dibutuhkan penambahan guru sebanyak 52.752 orang. Ini adalah angka yang ambisius dan mungkin utopis, dan karena itu sulit dipenuhi, baik dari segi pengadaan maupun terutama anggaran rekruitmen.

Analisis tersebut hanya melihat aspek kebutuhan guru dari segi jumlah. Tentu analisis berikutnya harus melihat secara lebih mendalam persoalan keragaman keahlian, kualifikasi, dan kompetensi yang harus disesuaikan dengan peningkatan keragaman program studi/kompetensi keahlian SMK sendiri. Jelas yang dimaksud dengan pertumbuhan siswa SMK, bukan sekedar meningkatkan kapasitas pada programprogram studi tradisional yang sudah ada, yang cenderung involutif. Justru, yang sangat penting, adalah pengembangan spektrum komptensi keahlian studi kontemporer yang relevan dengan konteks sumber daya lokal namun memiliki keunggulan nasional dan global, serta mengikuti perubahan ekonomi global, seperti industri kreatif misalnya. Dengan demikian, tidak terjadi apa yang analisis Martin (1994/2008), bahwa seringkali peningkatan kebutuhan ketrampilan tenaga kerja akibat perubahan ekonomi dunia, berlawanan dengan pendidikan teknologi kejuruan yang masih mengandalkan program ketrampilan berbasis kriya, industri manufaktur rakitan, dan agrikultur tradisional.

Kedua, peningkatan infrastruktur, baik berupa perbaikan/rehabilitasi/ renovasi bangunan lama SMK maupun pembangunan unit gedung sekolah baru yang mencakup ruang kelas, laboratorium, workshop/bengkel, dan studio. Dalam aspek ini, termasuk peningkatan kaulitas dan kuantitas peralatan pembelajaran, baik berupa pemutakhiran peralatan lama maupun penyediaan peralatan baru. Peralatan juga mencakup peralatan teknologi informasi dan komunikasi, yang akan menempatkan eksistensi SMK dalam konteks jaringan lokal, nasional, dan global.

Sarana pendidikan dibedakan menjadi 3 macam bila ditinjau dari hubungannya dengan proses belajar mengajar, yaitu: alat pelajaran, alat peraga, dan media pengajaran ( Amirin, 2010). Alat pelajaran adalah alat yang digunakan secara langsung dalam proses belajar mengajar, misalnya buku, alat tulis, dan alat praktik. Alat peraga adalah alat pembantu pendidikan dan pengajaran, dapat berupa perbuatan-perbuatan atau benda-benda yang mudah memberi pengertian kepada anak didik berturut-turut dari yang abstrak sampai dengan yang konkret. Media pengajaran. Media

pengajaran adalah sarana pendidikan yang digunakan sebagai perantara dalam proses belajar mengajar, untuk lebih mempertinggi efektivitas dan efisiensi dalam mencapai tujuan pendidikan.

Sedangkan prasarana pendidikan adalah semua perangkat kelengkapan dasar yang secara tidak langsung menunjang pelaksanaan pelaksanaan proses pendidikan di sekolah, yang diklasifikasikan menjadi dua macam. Pertama, prasarana pendidikan yang secara langsung digunakan untuk proses belajar mengajar, seperti ruang teori, ruang perpustakaan, ruang 
praktik keterampilan, dan ruang laboratorium. Kedua, prasarana sekolah yang keberadaannya tidak digunakan untuk proses belajar mengajar, tetapi secara langsung sangat menunjang terjadinya proses belajar mengajar, misalnya ruang kantor, kantin sekolah, tanah dan jalan menuju sekolah, kamar kecil, ruang usaha kesehatan sekolah, ruang guru, ruang kepala sekolah, dan tempat parkir kendaraan.

Dalam rangka mendukung proses pembelajaran secara optimal, sarana dan prasarana pendidikan harus memenuhi standar nasional atau internasional. Dalam lingkup nasional, standar berfungsi sebagai acuan dasar yang bersifat nasional bagi semua pihak yang berkepentingan, dalam tiga hal, yaitu (1) perencanaan dan perancangan sarana dan prasarana; (2) pelaksanaan pengadaan dan pemeliharaan sarana dan prasarana; dan (3) pengawasan ketersediaan dan kondisi sarana dan prasarana.

Pemenuhan Standar Sarana dan Prasarana Standar sarana dan prasarana merupakan kebutuhan utama sekolah juga yang harus terpenuhi sesuai dengan amanat UUSPN, Permendiknas No 24 Tahun 2007 dan No.40 Tahun 2008. Standar sarana dan prasarana pendidikan yang dimaksudkan di sini baik mengenai jumlah, jenis, volume, luasan, dan Iain-lain sesuai dengan kategori atau tipe sekolahnya masing-masing

Standar sarana dan prasarana SMK tertuang dalam Peraturan Mendiknas No.40 Tahun 2008. Berikut adalah penjelasan standar tersebut:

\section{Satuan pendidikan}

Satu SMK/MAK memiliki sarana dan prasarana yang dapat melayani minimum 3 rombongan belajar dan maksimum 48 rombongan belajar.

\section{Lahan}

Standar lahan mencakup : Luas lahan minimum dapat menampung sarana dan prasarana untuk melayani 3 rombongan belajar; Lahan efektif adalah lahan yang digunakan untuk mendirikan bangunan, infrastruktur, tempat bermain/berolahraga/upacara, dan praktik; Luas lahan efektif adalah seratus per tiga puluh (100/30) dikalikan luas lantai dasar bangunan ditambah infrastruktur, tempat bermain/berolahraga/upacara, dan luas lahan praktik; Lahan terhindar dari potensi bahaya yang mengancam kesehatan dan keselamatan jiwa, serta memiliki akses untuk penyelamatan dalam keadaan darurat; Kemiringan lahan rata-rata kurang dari 15\%, tidak berada di dalam garis sempadan sungai dan jalur kereta api, dan tidak menimbulkan potensi merusak sarana dan prasarana; Lahan terhindar dari gangguan-gangguan pencemaran air, kebisingan, pencemaran udara; Lahan sesuai dengan peruntukan lokasi yang diatur dalam Peraturan Daerah tentang Rencana Tata Ruang Wilayah Kabupaten/Kota, peraturan zonasi, atau rencana lain yang lebih rinci dan mengikat, serta mendapat izin pemanfaatan tanah dari Pemerintah Daerah setempat; Status kepemilikan/pemanfaatan hak atas tanah tidak dalam sengketa dan memiliki izin pemanfaatan dari pemegang hak atas tanah sesuai dengan ketentuan peraturan perundang-undangan yang berlaku untuk jangka waktu minimum 20 tahun.

\section{Bangunan}

Luas lantai bangunan dihitung berdasarkan banyak dan jenis program keahlian, serta banyak rombongan belajar di masing-masing program keahlian.

Bangunan memenuhi ketentuan tata bangunan berikut: Koefisien dasar bangunan mengikuti Peraturan Daerah atau maksimum $30 \%$ dari luas lahan di luar lahan praktik; Koefisien lantai bangunan dan ketinggian maksimum bangunan yang ditetapkan dalam Peraturan Daerah; Koefisien lantai bangunan dihitung berdasarkan luas lahan efektif; Jarak bebas bangunan yang meliputi garis sempadan bangunan dengan as jalan, tepi sungai, tepi pantai, jalan kereta api, dan/atau Saluran Udara Tegangan Tinggi (SUTT) atau Saluran Udara Tegangan Ekstra Tinggi (SUTET), jarak antara bangunan dengan batas-batas persil, dan jarak antara as jalan 
dan pagar halaman yang ditetapkan dalam Peraturan Daerah; Garis sempadan bangunan samping dan belakang mengikuti Peraturan Daerah atau minimum 5 meter.

Bangunan memenuhi persyaratan keselamatan berikut: Memiliki konstruksi yang stabil dan kukuh sampai dengan kondisi pembebanan maksimum dalam mendukung beban muatan hidup dan beban muatan mati, serta untuk daerah/zona tertentu kemampuan untuk menahan gempa dan kekuatan alam lainnya; Dilengkapi sistem proteksi pasif dan/atau proteksi aktif untuk mencegah dan menanggulangi bahaya kebakaran dan petir; Bangunan memenuhi persyaratan kesehatan berikut: Mempunyai fasilitas secukupnya untuk ventilasi udara dan pencahayaan sesuai dengan ketentuan yang berlaku; Memiliki sanitasi di dalam dan di luar bangunan meliputi saluran air bersih, saluran air kotor dan/atau air limbah, tempat sampah, dan saluran air hujan; Bahan bangunan yang aman bagi kesehatan pengguna bangunan dan tidak menimbulkan dampak negatif terhadap lingkungan; Bangunan menyediakan fasilitas dan aksesibilitas yang mudah, aman, dan nyaman termasuk bagi penyandang cacat.

Bangunan memenuhi persyaratan kenyamanan berikut: Bangunan mampu meredam getaran dan kebisingan yang mengganggu kegiatan pembelajaran; Setiap ruangan memiliki pengaturan penghawaan yang baik; Setiap ruangan dilengkapi dengan jendela yang tanpa atau dengan lampu penerangan dalam ruangan tersebut dapat memberikan tingkat pencahayaaan sesuai dengan ketentuan untuk melakukan kegiatan belajar.

Bangunan bertingkat memenuhi persyaratan berikut: Maksimum terdiri dari tiga lantai; Dilengkapi tangga yang mempertimbangkan kemudahan, keamanan, keselamatan, dan kesehatan pengguna.

Bangunan dilengkapi sistem keamanan berikut: Peringatan bahaya bagi pengguna, pintu keluar darurat dengan lebar minimum 1,2 meter, dan jalur evakuasi jika terjadi bencana kebakaran dan/atau bencana lainnya; Akses evakuasi yang dapat dicapai dengan mudah dan dilengkapi penunjuk arah yang jelas; Alat pemadam kebakaran pada area yang rawan kebakaran; Setiap ruangan dapat dikunci dengan baik saat tidak digunakan; Bangunan dilengkapi instalasi listrik dengan daya minimum 2.200 watt. Instalasi memenuhi ketentuan Peraturan Umum Instalasi Listrik (PUIL).

Pembangunan gedung atau ruang baru harus dirancang, dilaksanakan, dan diawasi secara profesional. Kualitas bangunan minimum permanen kelas B, sesuai dengan PP No. 19 Tahun 2005 Pasal 45, dan mengacu pada Standar PU. Bangunan SMK/MAK baru dapat bertahan minimum 20 tahun.

Pemeliharaan bangunan SMK/MAK adalah sebagai berikut: Pemeliharaan ringan, meliputi pengecatan ulang, perbaikan sebagian daun jendela/pintu, penutup lantai, penutup atap, plafon, instalasi air dan listrik, dilakukan minimum sekali dalam 5 tahun; Pemeliharaan berat, meliputi penggantian rangka atap, rangka plafon, rangka kayu, kusen, dan semua penutup atap, dilakukan minimum sekali dalam 20 tahun; Bangunan dilengkapi izin mendirikan bangunan dan izin penggunaan sesuai dengan ketentuan peraturan perundang-undangan yang berlaku.

Kelengkapan prasarana dan sarana. Sebuah SMK/MAK sekurang-kurangnya memiliki prasarana yang dikelompokkan dalam ruang pembelajaran umum, ruang penunjang, dan ruang pembelajaran khusus. Ketentuan mengenai kelompok ruang tersebut dijelaskan pada butir 1, butir 2, dan butir 3 beserta sarana yang ada di setiap ruang. Deskripsi yang lebih terinci tentang sarana dan prasarana pada masing-masing ruang pembelajaran khusus ditetapkan dalam pedoman teknis yang disusun oleh Direktorat Pembinaan SMK.

Kelompok Ruang Pembelajaran Umum terdiri dari: ruang kelas, ruang perpustakaan, ruang laboratorium biologi, ruang laboratorium fisika, ruang laboratorium kimia, ruang laboratorium IPA, ruang laboratorium komputer, ruang laboratorium bahasa, ruang praktik gambar teknik. Kelompok Ruang Penunjang terdiri dari: ruang pimpinan, ruang guru, ruang tata 
usaha, tempat beribadah, ruang konseling, ruang UKS, ruang organisasi kesiswaan, jamban, gudang, ruang sirkulasi, tempat bermain/berolahraga. Kelompok Ruang Pembelajaran Khusus meliputi ruang praktik yang disesuaikan dengan program keahlian.

\section{METODE PENELITIAN}

Pendekatan yang digunakan dalam penelitian ini adalah pendekatan kuantitatif deskriptif. Pendekatan ini dipilih karena sesuai dengan tujuan penelitian yaitu untuk mengetahui sejauh mana kondisi dan ketersediaan sarana dan prasarana Sekolah Menengah Kejuruan Negeri di kota Bandung dapat memenuhi standar yang telah ditetapkan pemerintah, sehingga hasilnya nanti dapat dijadikan bahan evaluasi atas kebijakan pemerintah mengenai peningkatan rasio SMK dan SMA menjadi 70:30.

Teknik pengumpulan data menggunakan dua cara. Pertama, pengumpulan data primer, yaitu melakukan observasi ke lokasi yang dijadikan sampel penelitian. Kedua, pengumpulan data Sekunder, yaitu mengumpulkan data berupa dokumen-dokumen. Dalam penelitian ini data langsung yang dihimpun dari instansi pendidikan yaitu Dinas Pendidikan Kota Bandung dan SMKN seluruh kota Bandung. Data yang dikumpulkan meliputi: data umum; data lahan; data bangunan; kelengkapan saranan dan prasarana.

Populasi yang diambil dalam penelitian ini adalah seluruh SMK Negeri di kota Bandung dengan jumlah 15 sekolah. Pengambilan sampel dilakukan dengan cara sampel total, yaitu mengambil sampel dari seluruh populasi yang ada. Sampel diambil dari 15 SMK Negeri di kota Bandung.

Sesuai dengan tipe penelitian, yaitu deskriptif, maka setelah data yang terkumpul, proses selanjutnya adalah menyederhanakan data yang diperoleh ke dalam bentuk yang mudah dibaca, dipahami dan diinterpretasi yang pada hakekatnya merupakan upaya peneliti untuk mencari jawaban atas permasalahan yang telah dirumuskan. Data yang diperoleh selanjutnya dianalisa secara kuantitatif, dengan mengolahnya ke dalam analisa statistika sederhana lalu kemudian ditarik kesimpulan. Berdasarkan hasil penelitian di lapangan maka untuk mengetahui pemenuhan standar, seluruh data dibandingkan dengan standar sarana dan prasarana yang mengacu pada peraturan Mendiknas nomor 40 tahun 2008 tentang sarana dan prasarana SMK.

\section{HASIL PENELITIAN}

\section{Data Umum}

Pada umumnya seluruh SMK Negeri di kota Bandung mengalami perkembangan setiap tahunnya baik jumlah siswa, guru maupun karyawan. Setiap sekolah memiliki jumlah siswa lebih dari tiga rombongan belajar, sesuai dengan peraturan yang mengharuskan tiap sekolah memiliki jumlah siswa minimum tiga rombongan belajar.

\section{Data Lahan}

Luas lahan seluruh SMKN di kota Bandung sekolah minimal dapat melayani tiga rombongan belajar. Namun seiring jumlah siswa yang cukup tinggi, maka luas minimum lahan harus disesuaikan dengan jumlah rombongan belajar atau sekitar $60 \%$ dari jumlah rombongan belajar. Atas dasar ini, temuan penelitian menunjukkan bahwa terdapat 10 sekolah yang tidak sesuai dengan luas minimum yang ditetapkan, sekolah tersebut adalah SMKN 1, SMKN 3, SMKN 7, SMKN 8, SMKN 9, SMKN 11, SMKN 12, SMKN 13, SMKN 14 dan SMKN 15 Bandung.

\section{Data Bangunan}

Aspek kesesuaian bangunan, dilihat dari pemenuhan persyaratan keselamatan, kesehatan, keamanan dan persyaratan bangunan lainnya. Berikut grafik hasil penelitian yang menggambarkan tingkat kesesuaian data bangunan dari lapangan dengan pemenuhan standar berdasarkan peraturan. 


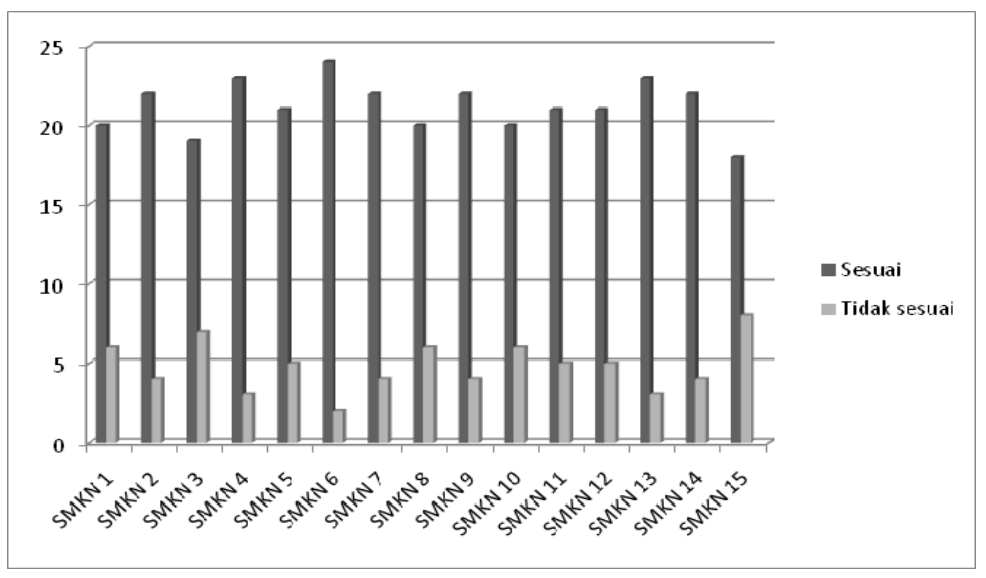

Grafik 1. Tingkat pemenuhan standar bangunan SMKN di Bandung

Merujuk pada diagram diatas, diketahui bahwa SMKN 6, SMKN 7, SMKN 9 dan SMKN 13 Bandung memiliki ketersesuaian paling tinggi terhadap pemenuhan standar bangunan sekolah. Namun demikian, secara umum setiap SMK belum dapat memenuhi standar nasional yang ditentukan.

\section{Data Kelengkapan Sarana dan Prasarana}

Sarana dan prasarana umum dan penunjang. Pada umumnya seluruh SMK Negeri di kota Bandung memiliki kelengkapan sarana dan prasarana umum dan penunjang yang hampir memadai, namun belum memenuhi standar. SMKN 9 Bandung adalah sekolah yang sarana dan prasarananya memiliki ketersesuaian paling tinggi dibandingkan sekolah-sekolah lainnya. Hal ini dapat dilihat pada tabel di bawah ini.

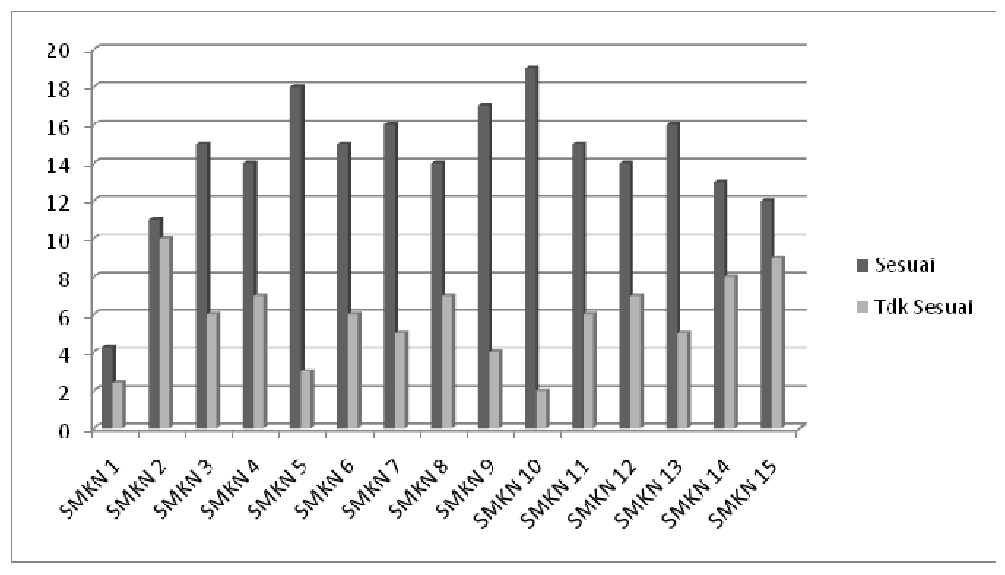

Grafik 2. Tingkat kesesuaian pemenuhan standar sarana dan prasarana SMKN kota Bandung 
Ruang pembelajaran khusus. Untuk lengkap dan memenuhi kebutuhan siswa. menunjang pembelajaran produktif Berikut diagram ketersesuaian pemenuhan dibutuhkan ruang khusus pembelajaran yang standar ruang khusus pembelajaran.

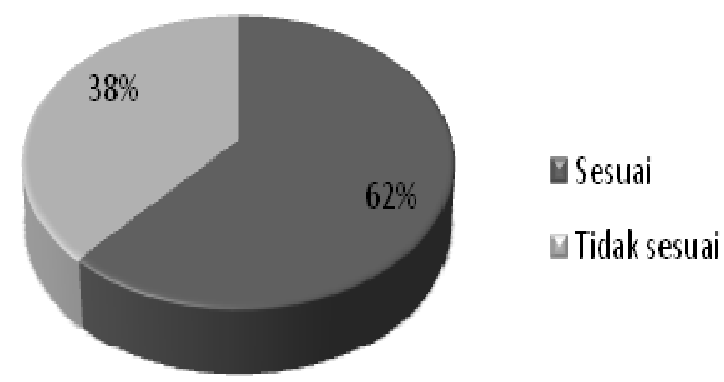

Grafik 3. Tingkat ketersediaan pemenuhan standar SMKN di kota Bandung

Dari tabel diatas, terlihat jelas bahwa ruang khusus pembelajaran SMK Negeri di kota Bandung $38 \%$ tidak sesuai. Hal ini disebabkan oleh kurangnya luas minimum ruangan dan kurang lengkapnya prasarana penunjang yang dibutuhkan siswa.

\section{Data Total}

Akhirnya, sesudah dikalkulasikan secara total mencakup lahan, bangunan, dan kelengkapannya, maka besaran persentase kesesuaian sarana dan prasarana SMK negeri di kota Bandung, adalah 75,8\% sekolah sesuai standar dan 24,19\% tidak sesuai dengan standar. Hal ini tergambar dalam diagram berikut

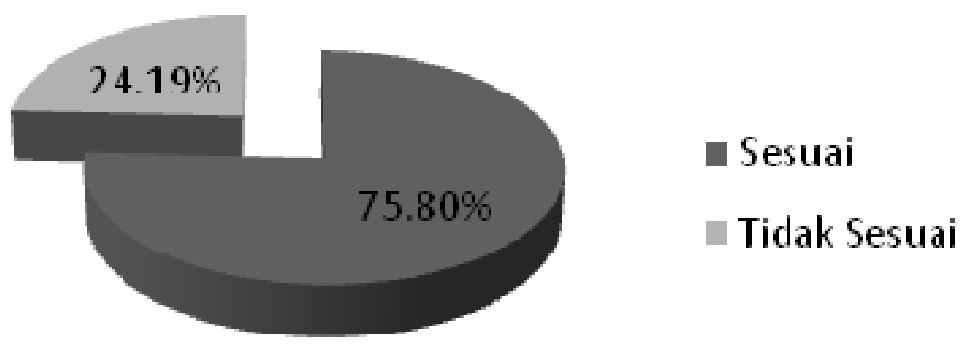

Grafik 4. Persentase pemenuhan standar SMKN di kota Bandung 


\section{KESIMPULAN DAN REKOMENDASI}

Jika dilihat secara komprehensif dengan menghitung secara akumulasi faktorfaktor lahan, bangunan, serta kelengkapan sarana dan prasarana, disimpulkan bahwa pada kondisi perbandingan siswa SMK : SMA saat ini di kota Bandung yang berkisar 50 : 50, terlihat bahwa infrastruktur SMK belum memenuhi standar. Secara umum, pemenuhan standar minimal sarana prasarana SMK adalah rata-rata 75\%. Penelitian ini ini baru mencakup SMK Negeri. Sementara itu, secara sekilas saja sudah bisa dilihat, bahwa kondisi sarana dan prasarana SMKSMK swasta jauh lebih buruk daripada SMK Negeri. Berdasarkan hasil penelitian tersebut, maka ada dua rekomendasi yang pantas dikemukakan untuk para penentu kebijakan di Kementrian Pendidikan Nasional pada tingkat pusat, daerah, dan pengelola SMK.

Pertama, kebijakan peningkatan rasio jumlah siswa SMK : SMA menjadi 70 : 30, selayaknya bukan didasarkan kepada pendekatan common sense atau pendekatan proyek belaka. Kebijakan ini seharusnya dibangun di atas landasan yang kokoh, misalnya ketersediaan sarana dan prasarana yang memenuhi standar, karena implementasi kebijakan bukan semata-mata menyangkut kuantitas tetapi juga kualitas pendidikan. Atas dasar ini, maka sudah selayaknya, peningkatan jumlah siswa melalui berbagai promosi, disertai juga dengan kebijakan untuk meningkatkan kuantitas dan kualitas sarana dan prasana pendidikan secara luar biasa.

Kedua, penelitian ini baru menyangkut sarana dan prasarana, belum menyangkut ketersediaan guru dari segi jumlah dan kualifikasi, ragam keahlian, dan kebutuhan pasar kerja. Semua itu, memerlukan penelitian dan perhitunganperhitungan. Menyangkut sarana dan prasarana misalnya, pada kondisi 50 : 50 saja, sebagian besar SMK baru dapat memenuhi standar 75\%. Dengan proyeksi sederhana tentu mudah dihitung, disimulasikan, dan lalu diimplementasikan pemenuhan standar kebutuhan sarana prasarana pada tahun 2014, pada saat siswa SMK dan SMA berbanding 70 : 30.

Jika kebijakan peningkatan jumlah siswa SMK tidak diikuti dengan perencanaan strategis penyediaan guru, sarana dan prasarana, dan bidang keahlian, maka akan berimplikasi pada kemunduran yang bersifat massif pada mutu pendidikan kejuruan di SMK. Tanda-tandanya terlihat. Misalnya, melalui kebijakan crash programm, seperti pengiriman mahasiswa tingkat akhir untuk menjadi guru sementara pada SMK-SMK misalnya, adalah bertentangan dengan upaya peningkatan profesionalisme guru dan peningkatan mutu pendidikan secara umum.

\section{DAFTAR PUSTAKA}

Amirin, Tatang M. (2010). Pengertian Sarana dan Prasarana Pendidikan. Tersedia di http://tatangmanguny.wordpress.com [15 April 2010]

As'ari, Deny Kurniawan (2009). Mengembangkan SMK Berbasis Industri. Tersedia di http//: ispi.or.id

Balitbang dan Dikdasmen. (1999). Memahami Kurikulum Sekolah Menengah Kejuruan Edisi 1999 Berpendekatan Competency Based dan Board Based. Jakarta: Balitbang dan Dikdasmen, Depdikbud.

Budiwati, Neti (2009). Kontribusi Pendidikan terhadap Pembangunan. Tersedia http//:netibudiwati.blogspot.com/200 9/4

Bunk, G. P. (1994). Teaching Competency in Initial and Continuing Vocational Training in the Federal Republic of Germany (CEDEFOP)

Butler, F.C. 1979. Instructional Systems Development for Vocational and Technical Training. Englewood Cliffs, N.J.: Educational Technology Publication.

Calhoun, C.C., Finch, A.V. 1982. Vocational Education: Concepts and Operations $\left(2^{\text {nd }}\right.$ ed.). Belmont, California: Wadworth Publishing Company. 
Hicks, N.L. 1992. Education and Economic Growth. Dalam Psacharopoulos, G. (Ed.), Economcis of Education, Research and Studies. Elkins Park, PA: Franklin Book Company, Inc.

International Labour Organization. (2004). Pengembangan Keterampilan Untuk Pertumbuhan Ekonomi dan Kehidupan yang Berkelanjutan. Survey ILO Divisi Indonesia : tidak diterbitkan

Ikatan Sarjana Ekonomi Indonesia/ISEI (2009). Memacu pertumbuhan ekonomi dan mendorong penciptaan lapangan kerja baru di Indonesia. http://www.isei.or.id/data/materi proceeding

Mulyadi, Yadi (2007). Ketersediaan Guru Teknologi dan Kejuruan dengan Proyeksi Pertumbuhan Siswa Memakai Skema SMA (40) : SMK (60). INVOTECH, Jurnal Pendidikan Teknologi dan Kejuruan, FPTK UPI.

Mutasya, Tata (2005). Kebijakan pasar tenaga kerja fleksibel: tepatkan untuk Indonesia saat ini? Policy assesment. Juni, 2005. Tersedia di www.theindonesianinstitute.com

Mustofa, Ali (2009).Sarana dan Prasarana Pendidikan.Tersedia di http://gendonne.blogspot.com/2009/ 11/sarana-dan-prasarana pendidikan.html, kutipan dari:kompas.com [15 April 2010]

Panduan Pelaksanaan tahun 2007. Program Imbal Swadaya Pengembangan Kota Vokasi. Jakarta: Direktorat PSMK, Depdiknas RI.
Permendiknas No.40 (2008). Standar Sarana dan Prasarana SMK. Jakarta: Dinas Pendidikan.

Pemprov Jabar dorong lulusan SMP Lanjutkan ke SMK (2009).[on line]. Tersedia di: http://Harian Umum Pakuan.com[15 April 2010)

PP 15 tahun 2005, tentang Standar Pendidikan Nasional

Pokok-pokok Pikiran: Ketrampilan Menjelang 2020 dan Perkembangannya (2001). Proyek Pengembangan Sistem dan Standard Pengelolaan SMK. Jakarta: Direktorat Dikmenjur Depdiknas

Technical and Vocational Education for The Twenty First Century. Section for Technical and Vocational Education, Unesco. Tersedia di http://www.unesco.org/education. In Focus Programme on Skills, Knowledge and Employability, ILO. Tersedia di http://www.ilo.org/skills/

The World Bank. 1991. Vocational and Technical Education and Training. Washington, D.C.: The World Bank.

Tingkat Pengangguran di Indonesia. [on line]. Tersedia di: http:// www.kompas.com.[16 April 2010]

Trout, Jack (2004). Trout on Strategy: Capturing Mindshare, Conquering Markets. London: McGraw Hill

Undang-Undang No. 14 tahun 2005 tentang Guru dan Dosen

Wahyudin, Iwan (2006), Evaluasi Penggunaan Peralatan Laboratorium Kayu Bidang Keahlian Teknik Bangunan SMKN 6 Bandung. Tidak diterbitkan. 